For submission to:

Cancer Epidemiology (REF compliant) http://www.cancerepidemiology.net/

\title{
Aspirin and other non-steroidal anti-inflammatory drug prescriptions and survival after the diagnosis of head and neck and oesophageal cancer
}

Tatiana V Macfarlane * , Peter Murchie, Margaret C. Watson

School of Medicine and Dentistry, University of Aberdeen

* Address for correspondence:

Dr Tatiana V Macfarlane

University of Aberdeen Dental School and Hospital

Cornhill Road, Foresterhill

Aberdeen, AB25 2ZR

United Kingdom

Email Tatiana.Macfarlane@abdn.ac.uk 


\section{Abstract}

Background: Aspirin and other NSAIDs are widely used as analgesics and the former is a preventative agent for vascular events. It is unclear whether their longterm use affects cancer risk. Data on the chemopreventative role of these drugs on the mortality in patients with upper aerodigestive tract cancer (UADT) are insufficient. The aim of this study was to investigate the effect of aspirin and other NSAIDs on survival in UADT cancer patients.

Methods: An observational cohort study of patients with UADT cancer was undertaken using Primary Care Clinical Informatics Unit (PCCIU) database of electronic medical records in Scotland. Information was available on all prescriptions of aspirin and other NSAIDs before and after diagnosis. The main outcome measure was all-cause mortality. Cox regression was used for statistical data analysis.

Results: There were 2,392 patients diagnosed with UADT cancer between 1996 and 2010. Mean age of patients was 66 years (SD 12) and most were male (63\%). Median survival in head and neck (HNC) patients was 94 months, while median survival in oesophageal cancer patients was 10 months. For HNC improved survival was observed with aspirin prescription (ever vs never Hazard Ratio (HR) 0.56 95\% Confidence Interval $(\mathrm{Cl}) 0.44,0.71$ ), there was no association with Cyclooxygenase 2 Inhibitors (COX-2) prescriptions. Improved survival was observed with other NSAIDs prescription (ever vs never HR $0.7495 \% \mathrm{Cl} 0.60,0.90$ ). For oesophageal cancer patients, improved survival was observed with aspirin prescriptions (ever vs never HR $0.5495 \% \mathrm{Cl} 0.45,0.64$ ), COX-2 prescriptions (HR $0.7895 \% \mathrm{Cl} 0.62,0.98$ ) and other NSAIDs (HR $0.6795 \% \mathrm{Cl} 0.56,0.80$ ).

Conclusions: Aspirin and other NSAIDs prescriptions after diagnosis are associated with a reduced all-cause mortality in UADT cancer patients.

Keywords: Aspirin; Non-steroidal anti-inflammatory agents; head and neck cancer; oesophageal cancer; survival; prognosis; Computerized Medical Records 


\section{Introduction}

Cancer of the upper aerodigestive tract (UADT) (oral cavity, pharynx, larynx and oesophagus combined) is, globally, the fourth most common cancer and cause of cancer mortality, with over million incident cases and over 700,000 deaths worldwide [1]. While a decrease in mortality was noted in the European Union (EU) overall between 1993 and 2004, a persistent rise was observed in central and eastern European countries [2]. European mean age-standardised 5-year relative survival was $39.9 \%$ for Head and Neck Cancer (HNC) and 12.4\% for cancer of the oesophagus [3].

Prophylactic aspirin has been considered to be beneficial in reducing the risks of heart disease and cancer. Previous research showed the decreased risk of cancer of the UADT associated with the use of non-COX-2 inhibitors, NSAIDs and long-term aspirin therapy $[4,5]$. Analysis of individual patient data from randomised clinical trials of daily aspirin [7] showed a significant reduction in death due to cancer, however there were no data reported in this study on HNC. Observational study by Rachidi et al [6] showed that post-diagnosis treatment of patients with head and neck squamous cell carcinoma with antiplatelet medications (including aspirin and other NSAIDs) was associated with better prognosis.

The aim of this study was to investigate the effect of aspirin and other NSAIDs use on the risk of UADT cancers. Specific objectives were to investigate risk by cancer subsite, duration of use and type of NSAIDs.

\section{Material and Methods}

An observational cohort study of patients with UADT cancer was undertaken using Primary Care Clinical Informatics Unit (PCCIU) database of electronic medical records in Scotland (http://www.abdn.ac.uk/pcciu/). PCCIU Research database includes data from more than 200 participating medical practices and approximately one million patients. Data reflect the computerized clinical record, including appointments, repeat and acute prescribing, call/recall, and screening. Ethical permission was not required as the data were anonymised and individuals could not be identified.

Patients with first time UADT cancer (oral cavity, oropharynx, hypopharynx, larynx and oesophagus) diagnosed in 1996 or later were identified using READ codes 
(http://systems.hscic.gov.uk/data/uktc/readcodes) as described in Table 1. Carcinoma in situ and patients aged $<18$ years at diagnosis were excluded. We used all the available eligible patients in the PCCIU database. Participants with cancer diagnosis before diagnosis with UADT cancer were excluded (READ codes B0\%, B1\%, B2\%, $\mathrm{B} 3 \%, \mathrm{~B} 4 \%, \mathrm{~B} 5 \%, \mathrm{~B} 6 \%, \mathrm{~B} 9 \%, \mathrm{BA} \%, \mathrm{BB} \%, \mathrm{By} \%)$.

Participants entered the study on the date of UADT cancer diagnosis and exited the study on the date of last appointment at their medical practice, date of deregistration with the practice or date of death. There was no information on cause of death.

To measure exposure, we identified prescriptions of oral aspirin, Cyclooxygenase 2 Inhibitors (COX-2) or other NSAIDs. Additional data in the database were available on patients' age at diagnosis, gender, practice deprivation (Carstairs index) [8], selfreported smoking status before diagnosis (never/ever) and most recent alcohol consumption (high consumption was defined as above the recommended limit of 2-3 units a day for women and 3-4 units a day for men). Information was also obtained on history of coronary heart disease (CHD), atrial fibrillation (AF) and stroke.

Analysis was conducted using IBM SPSS Statistics version 21 (IBM Corporation 2012) and STATA 13 (StataCorp LP, College Station, TX, USA 2013). We used Kaplan-Meier analysis to illustrate survival graphically and Log Rank test (MantelCox) to test for equality of survival distributions for different levels of medication use.

Hazard Ratios (HRs) with 95\% confidence intervals (Cls) adjusted for the potential confounding factors (age, gender, deprivation, smoking and alcohol consumption) were estimated using Cox regression model. Proportional hazards assumption was tested using stphtest and stphplot procedures in STATA. Continuous variables were categorised using median or tertiles of the overall distribution as appropriate. Age was a priori categorised as following: $18-55,56-65,66-75$ and $76-99$ years. Multiple imputation with ten imputed datasets was performed using mi procedure in STATA for smoking and alcohol consumption with all variables used in the analysis included in the imputation [9].

Additional analysis was conducted using nested case-control design. Those who had died were considered cases. These were matched on gender, age (within 5-years) 
and year of cancer diagnosis (within 2-years) separately for each site to one control who lived at least as long after diagnosis as the matched case. Conditional logistic regression was used to estimate Odds Ratios (ORs) with $95 \% \mathrm{Cl}$ adjusted for the potential confounding factors.

\section{Results}

We identified 2,392 patients with UADT cancer (1,195 of HNC and 1,197 oesophageal cancer) from 131 general medical practices (Table 1) between 1996 and 2010. Mean age of patients at diagnosis was 62 (SD 12) and 69 (SD 11) for HNC and oesophageal cancer respectively. The majority were males (70.2\% among HNC patients and $64.4 \%$ among oesophageal cancer patients). There were 509 (42.6\%) and 965 (80.6) deaths among HNC and oesophageal cancer patients, respectively. Median survival in HNC patients was 94 months (95\% Confidence Interval (Cl) 78, 120), while median survival in oesophageal cancer patients was 10 months $(95 \% \mathrm{Cl} 9,11)$.

Older age, male gender, deprivation, smoking, high (above the recommended limit) alcohol consumption, AF and stroke associated with poor survival in HNC patients. Among patients with oesophageal cancer, poor survival was associated with older age, male gender, smoking, CHD, AF, stroke and aspirin prescription before diagnosis (Table 2). For both cancer sites, 'later entry to the cohort was associated with shorter survival: HR $2.01(95 \% \mathrm{Cl} 1.56,2.60)$ in HNC patients and HR 1.64 (95\% Cl 1.36, 1.98) in oesophageal cancer patients diagnosed in 2006-2010 compared with 19962000.

Figure 1 shows survival by cancer site and medication. Results of the Log Rank test for HNC for aspirin, Cox-2 and other NSAIDs were $6.75(P=0.009), 2.34(P=0.126)$ and $27.43(P>0.001)$ respectively. Results of the Log Rank test for oesophageal cancer were $10.31(P=0.001)$ for aspirin, $6.69(P=0.01)$ for Cox-2 and $31.34(P<0.001)$ for other NSAIDs.

For HNC, improved survival was observed with aspirin prescription (ever vs never HR $0.5695 \% \mathrm{Cl} 0.44,0.71$ ), higher prescription density (defined as number of prescription divided by total follow up time) ( $\mathrm{HR} 0.55,95 \% \mathrm{Cl} 0.36,0.84$ for more than 6 prescriptions per year). There was no difference in prescription timing of aspirin: both 
first aspirin prescription within the first month (HR $0.4895 \% \mathrm{Cl} 0.29,0.81$ ) and first prescription later $(\mathrm{HR} 0.7095 \% \mathrm{Cl} 0.54,0.91)$ associated with a reduced mortality (Table 3). There was no association with ever COX-2 prescriptions but increased risk with increased prescription density $(\mathrm{HR} 3.5895 \% \mathrm{Cl} 1.81,7.10$ for 3 or more prescriptions per year) and for first prescription within a month since diagnosis (HR $4.9595 \% \mathrm{Cl} 3.03,8.09)$. However, these results are based on a limited number of patients and deaths. Improved survival was observed with other NSAIDs prescription (ever vs never HR $0.7495 \% \mathrm{Cl} 0.60,0.90$ ). Low prescription density of other NSAIDs (<3 per year) showed a reduction in $\operatorname{HR}(0.7795 \% \mathrm{Cl} 0.60,1.00)$ however higher prescription density ( $\geq 3$ prescriptions per year) was associated with increased risk of death (HR 1.65 95\% Cl 1.04, 2.63).

For oesophageal cancer patients, improved survival was observed with medicines of interest: aspirin prescriptions (ever vs never HR $0.5495 \% \mathrm{Cl} 0.45,0.64$ ), COX-2 prescriptions (HR $0.7895 \% \mathrm{Cl} 0.62,0.98$ ) and other NSAIDs (HR $0.6795 \% \mathrm{Cl} 0.56$, 0.80) (Table 3).

Using nested case-control design, there were 509 cases of deaths among HNC patients and 232 cases of deaths among oesophageal cancer patients with 1-to-1 matched controls. For aspirin, COX-2 and other NSAIDs prescriptions (ever vs never) ORs were as following: $0.85(95 \% \mathrm{Cl} 0.62,1.17), 1.32(95 \% \mathrm{Cl} 0.69,2.50)$ and 0.82 $(95 \% \mathrm{Cl} 0.62,1.08)$ for $\mathrm{HNC}$ and $0.75(95 \% \mathrm{Cl} 0.43,1.31), 0.70(95 \% \mathrm{Cl} 0.15,3.20)$ and $1.05(95 \% \mathrm{Cl} 0.60,1.84)$ for oesophageal cancer.

\section{Discussion}

This first large Scotland-based general practice-derived study of survival showed a decrease in risk of UADT cancer with aspirin prescriptions irrespective of timing after diagnosis or volume.

Other studies of cancer patients showed improved survival among those taking aspirin. In meta-analysis of eight trials (25 570 patients, 674 cancer deaths), allocation to aspirin reduced death due to cancer (pooled Odds Ratio (OR) 0.79, 95\% Cl 0.680.92) [7]. In further analysis of individual patient data from seven randomised trials of daily aspirin versus no aspirin, there were no data reported specifically on head and neck cancer, but there was a non-significant decrease in risk of death due to 
oesophageal cancer (HR 0.78 95\% Cl 0.27, 2.23 for 0-5 years of follow up and HR $0.4395 \% \mathrm{Cl} 0.11,1.72$ for 5 years follow up or longer) [7].

Study of aspirin use and survival after diagnosis of breast cancer showed a reduction in both all-cause (HR 0.53, 95\% Cl 0.45, 0.63) and breast-cancer specific mortality (HR 0.42, 95\% Cl 0.31, 0.55) [10]. In a prospective, observational study of aspirin and COX-2 inhibitor use and survival in stage III colon cancer patients enrolled in an adjuvant chemotherapy trial, aspirin use and COX-2 inhibitors use were associated with improved overall survival (HR $0.63,95 \% \mathrm{Cl} 0.35$ to 1.12$)$ and $0.50(95 \% \mathrm{Cl} 0.23$ to 1.07), respectively [11]. Study of treatment with antiplatelet medications (including aspirin and other NSAIDs) after diagnosis with head and neck squamous cell carcinoma was associated with longer overall survival [HR 0.76, 95\% Cl 0.58-0.99] [6].

The chemopreventive effect of aspirin and other NSAIDs has been partially attributed to their inhibition of the cyclo-oxygenase (COX) enzymes and reduced production of prostaglandins and other inflammatory mediators [7]. Platelets play a multifaceted and important role in cancer biology [12] and therefore development of platelet inhibitors that influence malignancy progression and study of currently available antiplatelet drugs represents a promising area of targeted cancer therapy [12,6].

The strength of this study is that as results are likely to be representative of the general population because the majority of the UK population is registered with a general medical practice.

However the study has several methodological deficiencies. The study had a limited sample size particularly for investigation of prescription density and prescription timing. No information was available regarding the histological sub-type, cancer stage or treatment. We could only investigate all-cause mortality as there was no information on cause of death. Study by Ning et al [13] reported that while cancer is the major cause of death among cancer patients, approximately half of participants died from other diseases and complications, such as cardiovascular and respiratory diseases. The authors concluded that clinicians and cancer survivors should pay attention to the prevention and treatment of other diseases and complications. 
For both cancer sites, 'later entry to the cohort was associated with shorter survival. These results may reflect differences in diagnostic tools, changes in clinical guidelines over time or some other residual confounding.

NSAID exposure was measured in terms of prescriptions issued and we did not have reliable information on dose or indication for use of aspirin or other NSAIDs. However Rothwell et al [7] reported that benefit of taking aspirin on cancer death was unrelated to aspirin dose (75 mg upwards). While low dose aspirin is mostly prescribed for prevention of cardiovascular events, other NSAIDs may be prescribed for cancer pain $[14,15]$. The issue of a prescription does not mean that the medicine was actually used. A questionnaire-based study conducted in UK general medical practices which compared prescribed NSAIDs and described by patients reported mean (SD) compliance (percentage of intended dose taken) of $0.73(0.55)$ for Ibuprofen, 0.76 (0.56) for diclofenac and $0.76(0.55)$ for naproxen [19].

No data were available regarding the use of over-the-counter medications which contain aspirin and NSAIDs, and this will have under-estimated exposure to these medicines. COX-2 inhibitors can only be obtained by prescription in the UK. However the reported prevalence of aspirin prescription is comparable with prevalence of selfreported aspirin use in other studies conducted in the UK [5] (22\% in patients with UADT cancer and $26 \%$ in healthy participants). Immeasurable time bias [16] could also have affected the results as the included patients might have been hospitalised and received drugs without there being a record in the general medical practice. However there was no data on hospitalisations available in the database.

Using 'ever' vs. 'never' categories for drug exposure also introduces immortal time bias [17] because it assumes that all participants had exposure to a drug from the start of follow-up. In observational studies some patients may not have survived to the day of their first prescription during follow-up, and may therefore have been classified as 'never users'. This could result in over-estimation of hazard ratios for 'ever' exposure to a drug. However unlike some treatments that may not be immediately available such as operations, aspirin (and some other NSAIDs) are easily available. In addition, we had prescription information both before and after diagnosis. In case of aspirin, the majority of patients (55\% with HNC and $77 \%$ with oesophageal cancer) who were prescribed aspirin after diagnosis also had 
prescriptions before diagnosis. They were more likely to be continuous users and therefore exposed at baseline. To investigate this bias further, sensitivity analysis was conducted using nested case-control design to test the validity of the results [18]. This analysis showed moderate non-significant reduction in risk of death associated with aspirin prescription for both HNC and oesophageal cancer. To reduce immortal time bias, future larger studies should investigate the use Cox models with time-dependent exposures. Such models will need to assess the length of prescriptions and to clarify the longest acceptable gap between prescriptions that constitute 'continuous use'. Such a model would also facilitate the addressing of issues such as increased risks of bleeding (aspirin and NSAID users) and increased risks of cardiovascular events, a common cause of death (NSAID and COX2 users).

Hernández-Díaz and García Rodríguez [20] in the study of NSAIDs and risk of lung cancer performed a sensitivity analysis to quantify the impact of misclassification due to unrecorded over-the-counter use or to non-compliance. They concluded that the protective effect could not be explained by the unrecorded use. Yood et al [21] concluded from their sensitivity analysis that prescription data can give valid estimates of association even though some of the drugs are available over-the-counter.

We defined ever users as those with at least one prescription. Another study of prescriptions [22] similarly defined users as those with at least one prescription, while Friis et al [23] defined users as those with two or more prescriptions. Studies which collected information using questionnaires defined users as those who ever taken aspirin before the onset of illness [24] or as regular users (use at least once a week for a year) [5].

While we adjusted for potential confounders such as deprivation, smoking and alcohol consumption, the quality of some of this information was poor. For example, there was a large amount of missing data for smoking (24\%) and alcohol consumption (35\%). We also used multiple imputation to replace the missing values for confounding factors.

In addition, we did not have information on other factors such history of HPV infection. It was shown that tumour HPV status is a strong and independent prognostic factor for survival among patients with oropharyngeal cancer [25]. 
There are risks associated with long term use of aspirin. A systematic review of observation studies of NSAIDs use showed an increased pooled Relative Risk of 3.8 (95\% Cl 3.6, 4.1) of upper gastrointestinal tract bleeding and perforation [26]. However Rothwell et al [27] in the study of individual patient data from 51 randomised trials of short-term effects of daily aspirin on cancer incidence, mortality, and non-vascular death showed that the reduced risk of major vascular events was initially offset by an increased risk of major bleeding, but effects on both outcomes diminished with increasing follow-up, leaving only the reduced risk of cancer from 3 years onwards. Case-fatality from major extracranial bleeds was also lower on aspirin than on control (Odds Ratio (OR) 0.32, 95\% Cl 0.12, 0.83).

Population-based cross-sectional European Eye Study of participants 65 years of age and older, showed that frequent aspirin use was associated with early and late aging macula disorder (AMD), and the ORs rose with increasing frequency of consumption. For daily aspirin users, the ORs, showed an increase with increasing severity of AMD grades: grade 1, $1.26(95 \% \mathrm{Cl} 1.08,1.46)$; grade $2,1.42(95 \% \mathrm{Cl}$ 1.18, 1.70), and wet late AMD, $2.22(95 \% \mathrm{Cl}, 1.61,3.05)$ [28].

Analysis of benefits and harms of prophylactic use of aspirin in the general population [29] suggested that in order to improve the benefit-harm ratio, future studies could identify individuals at high-risk of bleeding and either reduce their risk or not offer them prophylactic aspirin. Contraindications include peptic ulcer, recent bleeding episodes or bleeding tendencies. Other risk factors for bleeding in aspirin or NSAID users are increasing age, male sex, diabetes, hypertension, being overweight or obese, smoking, alcohol consumption and H. pylori infection [30].

\section{Conclusion}

Aspirin and other NSAIDs prescriptions after diagnosis are associated with a reduced all-cause mortality in UADT cancer patients. These results should be replicated in other prescriptions databases using statistical models with timedependent exposures and different study designs. Further research is also needed to determine the optimum dose and duration of use, and to identify individuals at increased risk of bleeding before starting aspirin prophylaxis.

\section{Acknowledgements}


We thank the PCCIUR staff and Data Management Team for preparing the data for this study: James Bellarby, Katie Wilde and Karen Lefevre.

We are grateful to the anonymous referees for very helpful comments and suggestions.

\section{References}

1. Ferlay J, Shin HR, Bray F, Forman D, Mathers C and Parkin DM (2010) GLOBOCAN 2008, Cancer Incidence and Mortality Worldwide: IARC CancerBase No. 10 [Internet]. Lyon, France: International Agency for Research on Cancer; Available from: http://globocan.iarc.fr

2. Garavello W, Bertuccio P, Levi F, Lucchini F, Bosetti C, Malvezzi M, Negri E, La Vecchia $C$ The oral cancer epidemic in central and eastern Europe. Int J Cancer 2001 127:160-171. doi: 10.1002/ijc.25019.

3. De Angelis R, Sant M, Coleman MP, Francisci S, Baili P, Pierannunzio D, Trama A, Visser O, Brenner H, Ardanaz E, Bielska-Lasota M, Engholm G, Nennecke A, Siesling S, Berrino F, Capocaccia R; EUROCARE-5 Working Group. Cancer survival in Europe $1999-2007$ by country and age: results of EUROCARE--5-a population-based study Lancet Oncol. 2014 Jan;15(1):2334. doi: 10.1016/S1470-2045(13)70546-1.

4. Macfarlane TV, Lefevre K, Watson MC. Aspirin and non-steroidal antiinflammatory drug use and the risk of upper aerodigestive tract cancer. $\mathrm{Br} \mathrm{J}$ Cancer. 2014 Sep 11. doi: 10.1038/bjc.2014.473

5. Macfarlane TV, Macfarlane GJ , Thakker NS, Benhamou S , Bouchardy C , Ahrens W, Pohlabeln H , Lagiou P, Lagiou A, Castellsague X , Agudo A , Slamova A , Plzak J, Merletti F , Richiardi L, Talamini R, Barzan L, Kjaerheim K, Canova C, Simonato L, Conway DI, McKinney PA, Thomson P, Sloan P , Znaor A, Healy CM, McCartan BE, Marron M, Brennan P (2012) Role of medical history and medication use in the aetiology of upper aerodigestive tract cancers in Europe: The ARCAGE study. Ann Oncol. 2012 23(4):1053-60 doi: 10.1093/annonc/mdr335

6. Rachidi S, Wallace K, Day TA, Alberg AJ, Li Z. Lower circulating platelet counts and antiplatelet therapy independently predict better outcomes in patients with head and neck squamous cell carcinoma. Journal of Hematology \& Oncology 2014, 7:65 doi:10.1186/s13045-014-0065-5

7. Rothwell PM, F Fowkes FGR, Belch JFF, Ogawa H, Warlow CP, Meade TW Effect of daily aspirin on long-term risk of death due to cancer: analysis of individual patient data from randomised trials. The Lancet 2011 377: 31-41. doi: 10.1016/S0140-6736(10)62110-1.

8. Carstairs $\mathrm{V}$ and Morris $\mathrm{R}$ Deprivation, mortality and resource allocation. Community Medicine, 198911 (4), 364-372. PMID:2634516 
9. White IR, Royston P, Wood AM. Multiple imputation using chained equations: Issues and guidance for practice. Stat Med 2011;30:377-99

10. Fraser DM, Sullivan FM, Thompson AM, McCowan C. Aspirin use and survival after the diagnosis of breast cancer: a population-based cohort study. British Journal of Cancer 2014 111, 623-627 doi:10.1038/bjc.2014.264

11. Ng K, Meyerhardt JA, Chan AT, Sato K, Chan JA, Niedzwiecki D, Saltz LB, Mayer RJ, Benson AB 3rd, Schaefer PL, Whittom R, Hantel A, Goldberg RM, Venook AP, Ogino S, Giovannucci EL, Fuchs CS. Aspirin and COX-2 inhibitor use in patients with stage III colon cancer. J Natl Cancer Inst. 2014 Nov 27;107(1):345. doi: 10.1093/jnci/dju345. Print 2015 Jan.

12. Bambace NM, Holmes CE. The platelet contribution to cancer progression. J Thromb Haemost 2011; 9: 237-49.

13. Ning Y, Shen Q, Herrick K, Mikkelsen R, Anscher M, Houlihan R, Lapane K. Cause of death in cancer survivors [abstract] In: Proceedings of the 103rd Annual Meeting of the American Association for Cancer Research; 2012 Mar 31-Apr 4; Chicago, Illinois. Philadelphia (PA): AACR; 2012. Abstract nr LB-339 http://www.abstractsonline.com/Plan/ViewAbstract.aspx?sKey=3641e61c689d-4092-8384-c7b6be9600fa\&cKey=716c7bb6-6b57-4a33-bf9616cc1db37bf4\&mKey=\{2D8C569E-B72C-4E7D-AB3B-070BEC7EB280\}

14. Macfarlane TV, Wirth T, Ranasinghe S, Ah-See KW, Renny N, Hurman D. Head and neck cancer pain: systematic review of prevalence and associated factors. J Oral Maxillofac Res. 2012 Apr 1;3(1):e1. doi: 10.5037/jomr.2012.3101.

15. Trotter PB, Norton LA, Loo AS, Munn JI, Voge E, Ah-See KW, Macfarlane TV. Pharmacological and other interventions for head and neck cancer pain: a systematic review. J Oral Maxillofac Res. 2013 Jan 1;3(4):e1. doi: 10.5037/jomr.2012.3401.

16. Suissa S. Immeasurable Time Bias in Observational Studies of Drug Effects on Mortality. Am J Epidemiol 2008;168(3):329-35

17. Suissa S. Immortal Time Bias in Pharmacoepidemiology. Am J Epidemiol 2008;167(4):492-99

18. Suissa S. Novel Approaches to Pharmacoepidemiology Study Design and Statistical Analysis. In: Strom BL, ed. Pharmacoepidemilolgy: John Wiley \& Sons, Ltd; 2005:811-29.

19. Seager JM, Cullen DJ, Pearson G, Holmes S, Doherty M, Wilson JV, Garrud P, Garner S, Maynard A, Logan RF, Hawkey CJ. Ibuprofen versus other nonsteroidal anti-inflammatory drugs: use in general practice and patient perception. Alimentary Pharmacology \& Therapeutics 2000, 14:187-191. PMID:10651659

20. Hernández-Díaz S, García Rodríguez LA. Nonsteroidal anti-inflammatory drugs and risk of lung cancer. Int J Cancer. 2007 120(7):1565-72.

PMID:17205530

21. Yood MU, Campbell UB, Rothman KJ, Jick SS, Lang J, Wells KE, Jick H, Johnson CC. Using prescription claims data for drugs available over-thecounter (OTC). Pharmacoepidemiol Drug Saf. 2007 16(9):961-8.

PMID:17654746 
22. Vinogradova Y, Coupland C, Hippisley-Cox J. Exposure to cyclooxygenase-2 inhibitors and risk of cancer: nested case-control studies. Br J Cancer. 2011 105(3):452-9. doi: 10.1136/bmj.39609.449676.25.

23. Friis S, Poulsen A, Pedersen L, Baron JA, Sørensen HT. Use of nonsteroidal anti-inflammatory drugs and risk of oral cancer: a cohort study. $\mathrm{Br} \mathrm{J}$ Cancer. 2006 95:363-365. PMID:16868546

24. Jayaprakash V, Rigual NR, Moysich KB, Loree TR Sullivan Nasca MA, Menezes RJ, Reid ME. Chemoprevention of Head and Neck Cancer With Aspirin Arch Otolaryngol Head Neck Surg. 2006 132:1231-1236 PMID:17116820

25. Ang KK, Harris J, Wheeler R, Weber R, Rosenthal DI, Nguyen-Tân PF, Westra WH, Chung CH, Jordan RC, Lu C, Kim H, Axelrod R, Silverman CC, Redmond KP, Gillison ML. Human Papillomavirus and Survival of Patients with Oropharyngeal Cancer N Engl J Med 2010 doi: 10.1056/NEJMoa0912217

26. Hernández-Díaz S, Rodríguez LA. Association between nonsteroidal antiinflammatory drugs and upper gastrointestinal tract bleeding/perforation: an overview of epidemiologic studies published in the 1990s. Arch Intern Med. 2000 160(14):2093-9. PMID:10904451

27. Rothwell PM, Price JF, Fowkes FG, Zanchetti A, Roncaglioni MC, Tognoni G, Lee R, Belch JF, Wilson M, Mehta Z, Meade TW. Short-term effects of daily aspirin on cancer incidence, mortality, and non-vascular death: analysis of the time course of risks and benefits in 51 randomised controlled trials. Lancet. 2012 379(9826):1602-12. doi: 10.1016/S0140-6736(11)61720-0

28. de Jong PT, Chakravarthy U, Rahu M, Seland J, Soubrane G, Topouzis F, Vingerling JR, Vioque J, Young I, Fletcher AE. Associations between aspirin use and aging macula disorder: the European Eye Study. Ophthalmology. 2012 Jan;119(1):112-8. doi: 10.1016/j.ophtha.2011.06.025. Epub 2011 Sep 13.

29. Cuzick J, Thorat MA, Bosetti C, Brown PH, Burn J, Cook NR, Ford LG, Jacobs EJ, Jankowski JA, La Vecchia C, Law M, Meyskens F, Rothwell PM, Senn HJ, Umar A. Estimates of benefits and harms of prophylactic use of aspirin in the general population. Ann Oncol. 2015 Jan;26(1):47-57. doi: 10.1093/annonc/mdu225.

30. Kaufman DW, Kelly JP, Wiholm BE, Laszlo A, Sheehan JE, Koff RS, Shapiro $S$. The risk of acute major upper gastrointestinal bleeding among users of aspirin and ibuprofen at various levels of alcohol consumption. Am J Gastroenterol 1999; 94: 3189-3196. PMID:10566713 
Table 1. Description of patients with UADT cancer included in the study

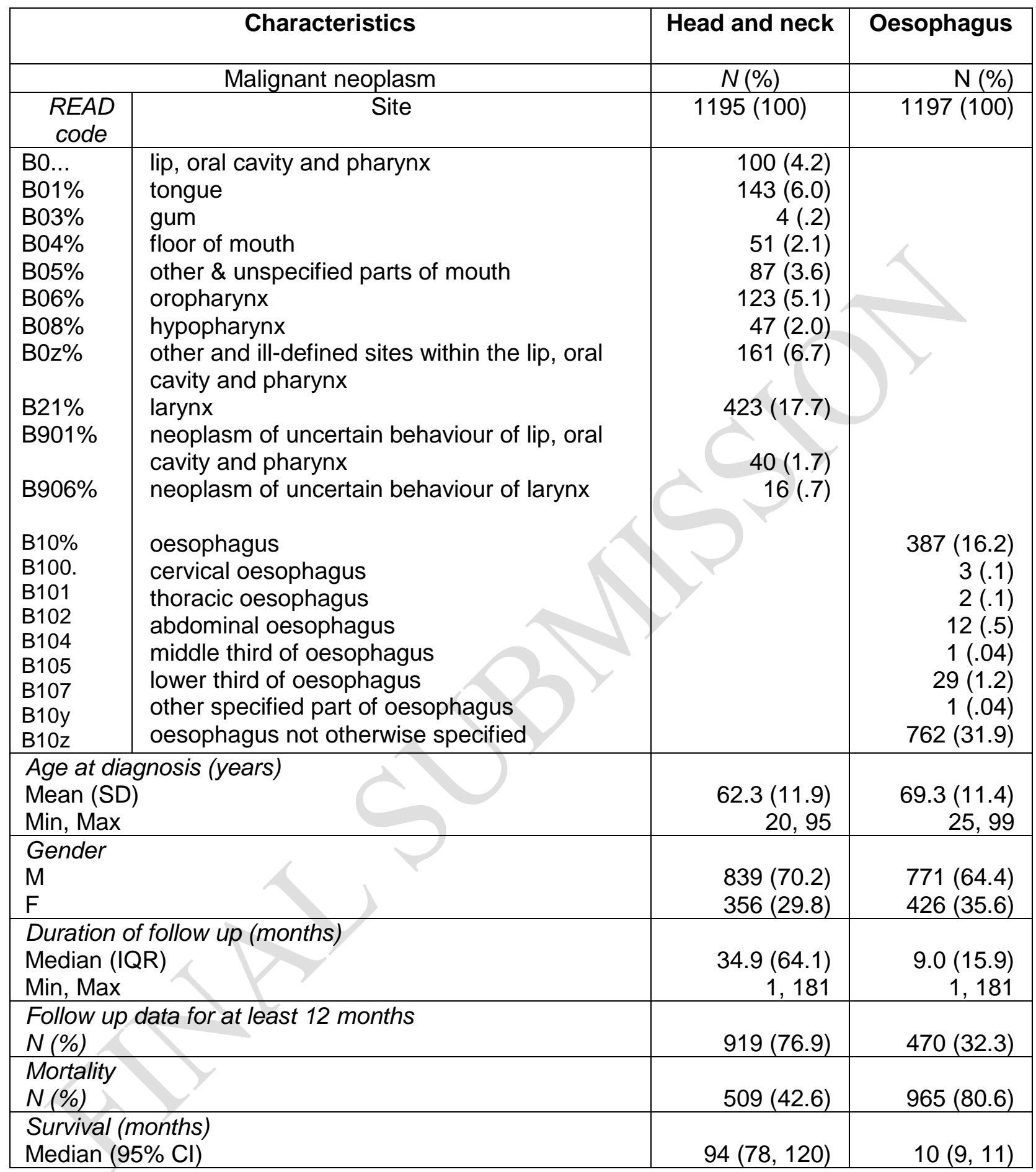

IQR - interquartile range 
Table 2. Factors associated with all-cause mortality in UADT cancer patients

\begin{tabular}{|c|c|c|c|c|c|c|}
\hline \multirow[t]{2}{*}{ Characteristic } & \multicolumn{3}{|c|}{$\begin{array}{c}\text { HNC cancer } \\
(n=1,195)\end{array}$} & \multicolumn{3}{|c|}{$\begin{array}{c}\text { Oesophageal cancer } \\
(n=1,197)\end{array}$} \\
\hline & $\mathbf{N}$ & $\mathbf{N}(\%)$ died & $\begin{array}{c}\text { Hazard ratio } \\
(95 \% \mathrm{Cl}) \#\end{array}$ & $\mathbf{N}$ & $\mathbf{N}(\%)$ died & $\begin{array}{c}\text { Hazard ratio } \\
(95 \% \mathrm{Cl}) \#\end{array}$ \\
\hline $\begin{array}{l}\text { Age at diagnosis } \\
18-55 \\
56-65 \\
66-75 \\
76-99\end{array}$ & $\begin{array}{l}321 \\
391 \\
333 \\
150\end{array}$ & $\begin{array}{l}92(28.7) \\
161(41.2) \\
162(48.65) \\
94(62.67)\end{array}$ & $\begin{array}{l}1.00 \\
1.56(1.21,2.02) \\
2.10(1.63,2.72) \\
4.05(3.02,5.43)\end{array}$ & $\begin{array}{l}144 \\
277 \\
375 \\
401\end{array}$ & $\begin{array}{l}106(73.6) \\
210(75.8) \\
299(79.7) \\
350(87.3)\end{array}$ & $\begin{array}{l}1.00 \\
1.24(0.98,1.56) \\
1.38(1.10,1.72) \\
1.93(1.54,2.41)\end{array}$ \\
\hline $\begin{array}{l}\text { Gender } \\
\mathrm{M} \\
\mathrm{F}\end{array}$ & $\begin{array}{l}839 \\
356\end{array}$ & $\begin{array}{l}374(44.6) \\
135(37.9)\end{array}$ & $\begin{array}{l}1.00 \\
0.75(0.62,0.92)\end{array}$ & $\begin{array}{l}771 \\
427\end{array}$ & $\begin{array}{l}627(81.3) \\
338(79.3)\end{array}$ & $\begin{array}{l}1.00 \\
0.86(0.75,0.98)\end{array}$ \\
\hline $\begin{array}{l}\text { Carstairs } \\
\text { Deprivation } \\
1 \text { (most affluent) } \\
2 \\
3 \\
4 \\
5 \\
6 \\
7 \text { (most deprived) }\end{array}$ & $\begin{array}{l}55 \\
85 \\
154 \\
406 \\
186 \\
135 \\
174 \\
\end{array}$ & $\begin{array}{l}17(30.9) \\
26(30.6) \\
61(39.6) \\
172(42.4) \\
80(43.0) \\
69(51.1) \\
84(48.3) \\
\end{array}$ & $\begin{array}{l}1.00 \\
1.36(0.74,2.50) \\
1.16(0.68,2.00) \\
1.68(1.02,2.77) \\
1.54(0.91,2.62) \\
2.10(1.24,3.58) \\
2.14(1.27,3.60)\end{array}$ & $\begin{array}{l}39 \\
114 \\
250 \\
379 \\
194 \\
124 \\
97 \\
\end{array}$ & $\begin{array}{l}33(84.6) \\
89(78.1) \\
203(81.2) \\
301(79.4) \\
156(80.4) \\
100(80.7) \\
83(85.6) \\
\end{array}$ & $\begin{array}{l}1.00 \\
1.04(0.69,1.55) \\
0.96(0.66,1.38) \\
0.99(0.69,1.41) \\
1.05(0.72,1.54) \\
0.93(0.63,1.38) \\
1.22(0.81,1.83)\end{array}$ \\
\hline $\begin{array}{l}\text { Year of diagnosis } \\
1996-2000 \\
2001-2005 \\
2006-2010\end{array}$ & $\begin{array}{l}303 \\
420 \\
472 \\
\end{array}$ & $\begin{array}{l}145(47.9) \\
204(48.6) \\
160(33.9) \\
\end{array}$ & $\begin{array}{l}1.00 \\
1.48(1.18,1.87) \\
2.01(1.56,2.60) \\
\end{array}$ & $\begin{array}{l}219 \\
487 \\
491 \\
\end{array}$ & $\begin{array}{l}184(84.0) \\
417(85.6) \\
364(74.1) \\
\end{array}$ & $\begin{array}{l}1.00 \\
1.48(1.24,1.77) \\
1.64(1.36,1.98)\end{array}$ \\
\hline $\begin{array}{l}\text { Smoking } \\
\text { Never } \\
\text { Ever } \\
\text { Missing } \\
\end{array}$ & $\begin{array}{l}141 \\
752 \\
302 \\
\end{array}$ & $\begin{array}{l}34(24.1) \\
337(44.8) \\
371(41.6) \\
\end{array}$ & $\begin{array}{l}1.00 \\
2.33(1.62,3.35)\end{array}$ & $\begin{array}{l}312 \\
618 \\
267 \\
\end{array}$ & $\begin{array}{l}246(78.9) \\
498(80.6)\end{array}$ & $\begin{array}{l}1.00 \\
1.21(1.04,1.42)\end{array}$ \\
\hline $\begin{array}{l}\text { Alcohol } \\
\text { consumption } \\
\text { No / Low } \\
\text { High \#\# } \\
\text { Missing }\end{array}$ & $\begin{array}{l}630 \\
135 \\
430 \\
\end{array}$ & $\begin{array}{l}253(40.2) \\
63(46.7)\end{array}$ & $\begin{array}{l}1.00 \\
1.52(1.14,2.06)\end{array}$ & $\begin{array}{l}728 \\
64 \\
405 \\
\end{array}$ & $\begin{array}{l}586(80.5) \\
50(78.1)\end{array}$ & $\begin{array}{l}1.00 \\
1.20(0.89,1.62)\end{array}$ \\
\hline $\begin{array}{l}\text { CHD } \\
\text { No } \\
\text { Yes } \\
\end{array}$ & $\begin{array}{l}1005 \\
190 \\
\end{array}$ & $\begin{array}{l}415(41.3) \\
94(49.5)\end{array}$ & $\begin{array}{l}1.00 \\
0.95(0.75,1.20)\end{array}$ & $\begin{array}{l}970 \\
227 \\
\end{array}$ & $\begin{array}{l}769(79.3) \\
196(86.3) \\
\end{array}$ & $\begin{array}{l}1.00 \\
1.23(1.04,1.44)\end{array}$ \\
\hline $\begin{array}{l}A F \\
\text { No } \\
\text { Yes }\end{array}$ & $\begin{array}{l}1153 \\
42\end{array}$ & $\begin{array}{l}482(41.8) \\
27(64.3)\end{array}$ & $\begin{array}{l}1.00 \\
1.67(1.12,2.49)\end{array}$ & $\begin{array}{l}1127 \\
70\end{array}$ & $\begin{array}{l}900(79.9) \\
65(92.9)\end{array}$ & $\begin{array}{l}1.00 \\
1.32(1.02,1.70)\end{array}$ \\
\hline $\begin{array}{l}\text { Stroke } \\
\text { No } \\
\text { Yes }\end{array}$ & $\begin{array}{l}1132 \\
63 \\
\end{array}$ & $\begin{array}{l}477(42.1) \\
32(50.8)\end{array}$ & $\begin{array}{l}1.00 \\
1.50(1.04,2.15)\end{array}$ & $\begin{array}{l}1143 \\
54\end{array}$ & $\begin{array}{l}922(80.7) \\
43(79.6) \\
\end{array}$ & $\begin{array}{l}1.00 \\
1.39(1.02,1.89)\end{array}$ \\
\hline $\begin{array}{l}\text { Aspirin } \\
\text { prescription } \\
\text { before diagnosis } \\
\text { No } \\
\text { Yes }\end{array}$ & $\begin{array}{l}886 \\
309\end{array}$ & $\begin{array}{l}366(41.3) \\
143(46.3) \\
\end{array}$ & $\begin{array}{l}1.00 \\
1.11(0.90,1.36)\end{array}$ & $\begin{array}{l}810 \\
387\end{array}$ & $\begin{array}{l}629(77.7) \\
336(86.8) \\
\end{array}$ & $\begin{array}{l}1.00 \\
1.38(1.20,1.59)\end{array}$ \\
\hline $\begin{array}{l}\text { COX-2 } \\
\text { prescription } \\
\text { before diagnosis } \\
\text { No } \\
\text { Yes }\end{array}$ & $\begin{array}{l}1145 \\
50\end{array}$ & $\begin{array}{l}488(42.6) \\
21(42.0)\end{array}$ & $\begin{array}{l}1.00 \\
0.99(0.64,1.54)\end{array}$ & $\begin{array}{l}1128 \\
69\end{array}$ & $\begin{array}{l}916(81.2) \\
49(71.0)\end{array}$ & $\begin{array}{l}1.00 \\
0.94(0.71,1.26)\end{array}$ \\
\hline $\begin{array}{l}\text { Other NSAID } \\
\text { before diagnosis } \\
\text { No } \\
\text { Yes }\end{array}$ & $\begin{array}{l}763 \\
432 \\
\end{array}$ & $\begin{array}{l}349(45.7) \\
160(37.0) \\
\end{array}$ & $\begin{array}{l}1.00 \\
0.94(0.78,1.14)\end{array}$ & $\begin{array}{l}759 \\
438 \\
\end{array}$ & $\begin{array}{l}618(81.4) \\
347(79.2) \\
\end{array}$ & $\begin{array}{l}1.00 \\
1.11(0.97,1.26)\end{array}$ \\
\hline
\end{tabular}

\# From Cox regression adjusted for age, gender and deprivation \#\# High consumption is defined as above the recommended limit 
Table 3. Aspirin, COX-2 and Other NSAIDs prescriptions after diagnosis of UADT cancer and all-cause mortality

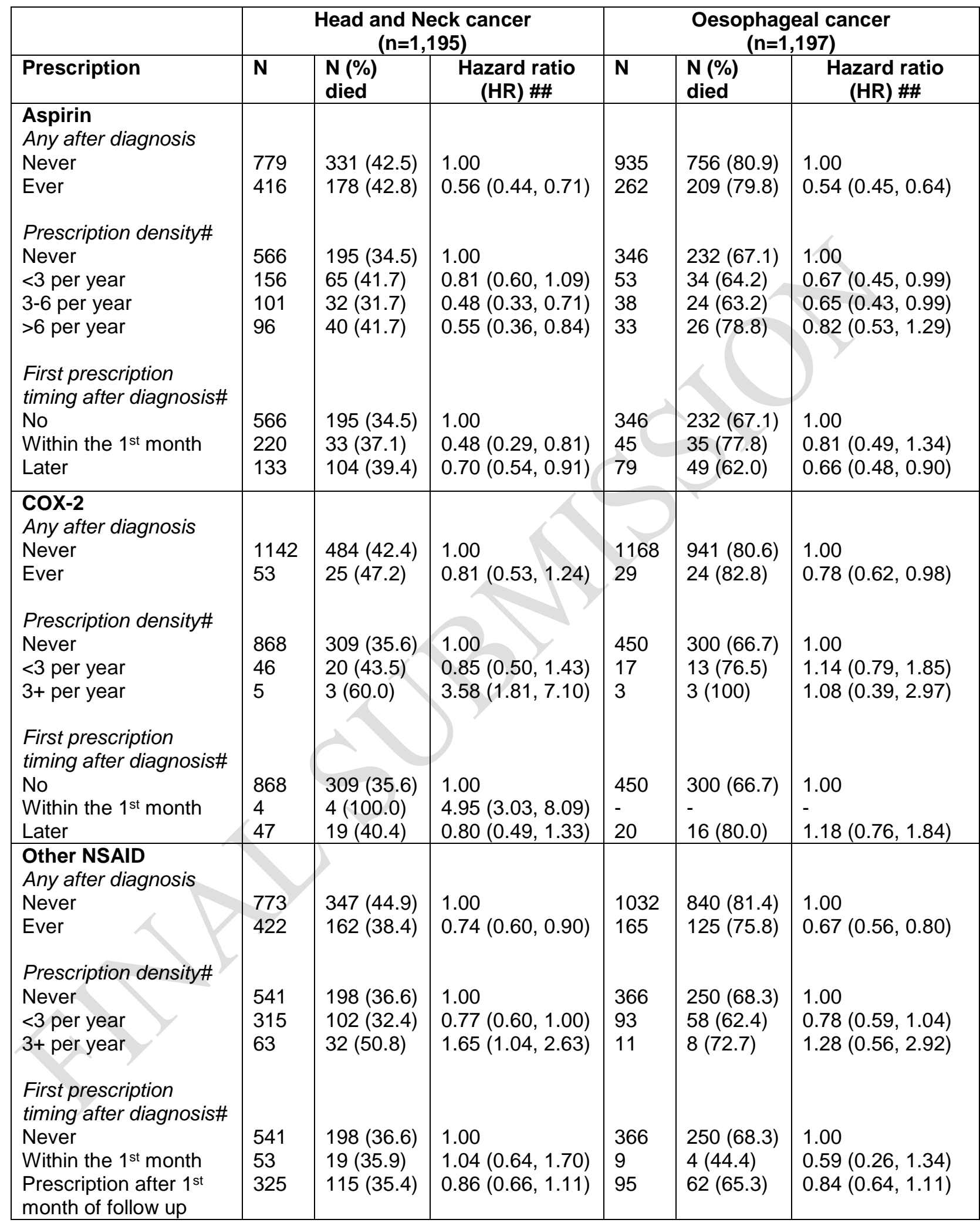

\# Among those surviving for more than 12 months

\#\# Adjusted for age, gender, deprivation, year of diagnosis, smoking (ever), alcohol consumption (high), CHD, AF, Stroke, Aspirin ((before and after diagnosis ), COX-2 (before and after diagnosis), other NSAID (before and after diagnosis) and taking into account clustering within medical practices

Prescription density was calculated as Number of prescriptions divided by follow up time 
Figure 1. Prescriptions after diagnosis and survival

HNC
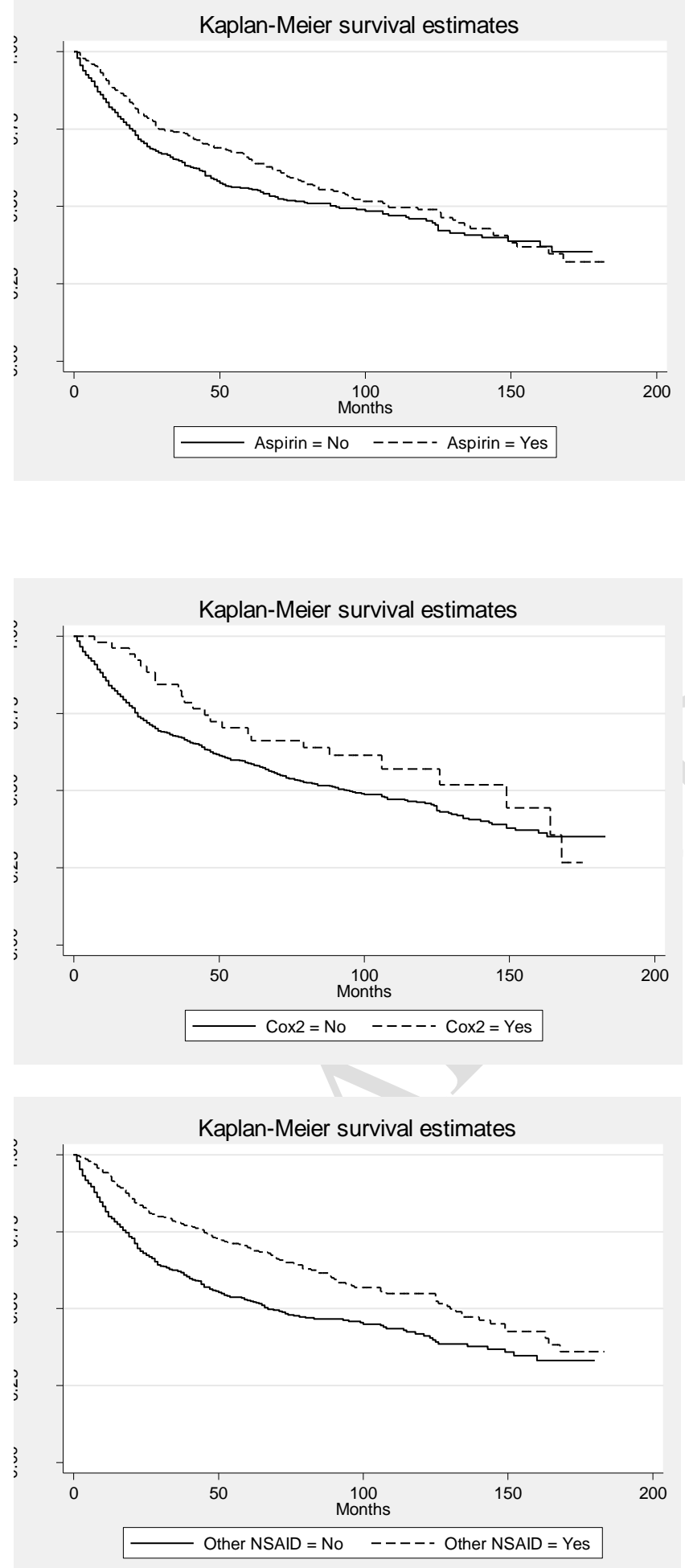

Oesophageal cancer

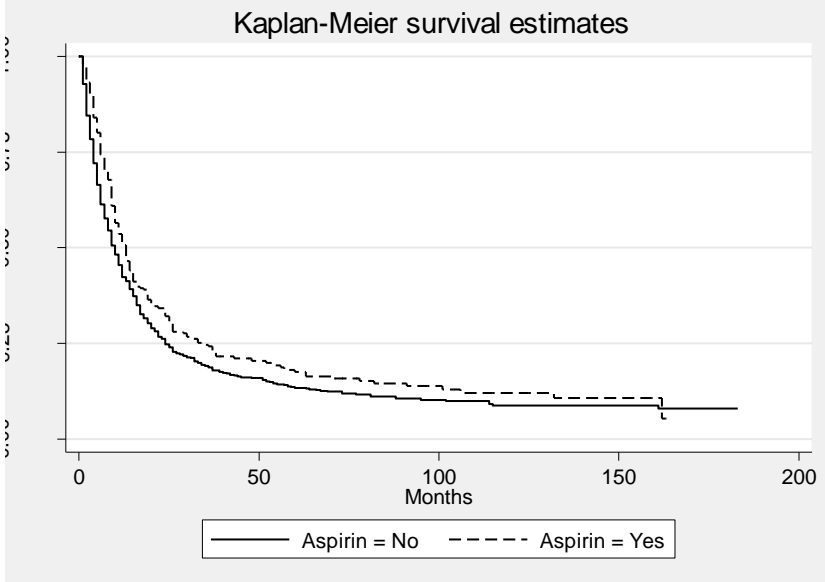

Kaplan-Meier survival estimates

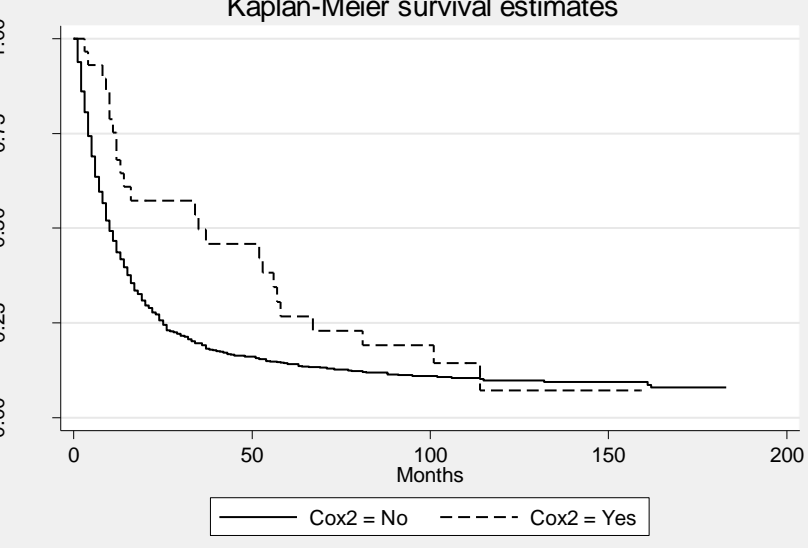

Kaplan-Meier survival estimates

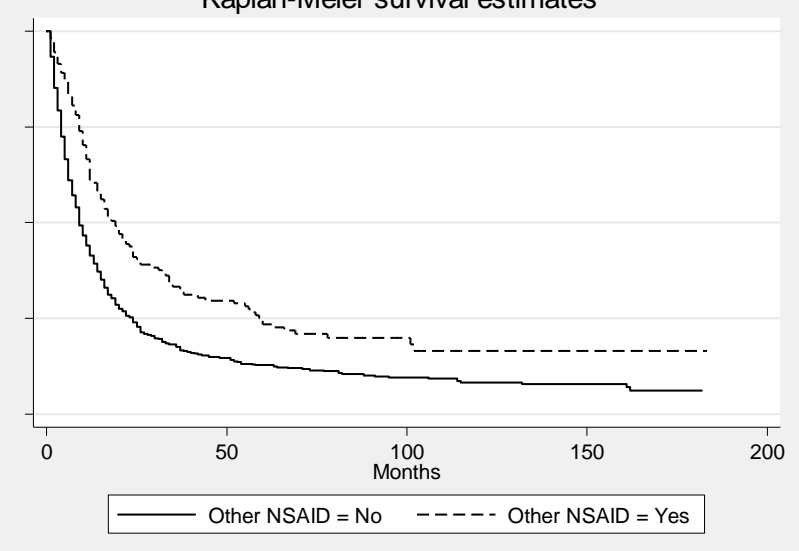

